\title{
Perceived Availability and Management of Garcinia buchananii Fruit Tree Species in the Lake Victoria Basin Districts of Rwanda and Uganda
}

\author{
Celestin Bigirimana ${ }^{1,2, *}$, Francis Omujal ${ }^{3,4}$, Prossy Isubikalu ${ }^{2}$, Elias Bizuru ${ }^{5}$, Bernard B. Obaa ${ }^{2}$, \\ Michael Malinga ${ }^{6}$, Jacob Godfrey Agea $^{2}$, John BoscoLamoris Okullo $^{4}$ \\ ${ }^{1}$ Center for Language Enhancement, College of Arts and Social Sciences, University of Rwanda, Rwanda \\ ${ }^{2}$ Department of Extension and Innovation Studies, School of Agricultural Sciences, College of Agricultural and Environmental \\ Sciences, Makerere University, Uganda \\ ${ }^{3}$ Ministry of Health, Natural Chemotherapeutics Research Institute, Uganda \\ ${ }^{4}$ Department of Forestry, Bio-Diversity and Tourism, School of Forestry, Environmental and Geographical Sciences, College of \\ Agricultural and Environmental Sciences, Makerere University, Uganda \\ ${ }^{5}$ Department of Biology, School of Sciences, College of Sciences and Technology, University of Rwanda, Rwanda \\ ${ }^{6}$ National Forestry Authority, Uganda
}

Copyright $(\subset 2016$ Copyright $(\underset{2}{ } 2016$ by authors, all rights reserved. Authors agree that this article remains permanently open access under the terms of the Creative Commons Attribution License 4.0 international License.

\begin{abstract}
This study explored community knowledge on availability and management of Garcinia buchananii in the Lake Victoria Basin (LVB) districts of Rwanda and Uganda. Specifically, it was conducted in Bugesera and Kirehe districts (Rwanda), and Buikwe and Masaka districts (Uganda). Household surveys, key informant interviews, focus group discussions (FGDs) and case studies were conducted to ascertain the availability status, ecological niche(s), propagation techniques as well as management practices of Garcinia buchananii. Garcinia buchananii was reported to be mostly abundant $(0.329 \pm 0.471)$ in the garden and wild. The highly reported methods of propagating were by use of seeds (87.8\% in Uganda and $85.4 \%$ in Rwanda). In Uganda, knowledge on propagation techniques was influenced by occupation $\left(\mathrm{R}^{2}=0.084 ; \mathrm{P}=0.05\right)$ while in Rwanda, none of the socio-demographic characteristics influenced knowledge on propagation of the species. The most common reported practices for managing Garcinia buchananii included weeding, mulching, watering and pruning. Since rural farming communities have always been exploiting indigenous fruit trees for their livelihoods, increased awareness and use of proper extension services plus provision of planting materials could lead to wise use and management of Garcinia buchananii in the LVB districts of Rwanda and Uganda.
\end{abstract}

Keywords Garcinia buchananii, Indigenous Fruit Trees, Community Knowledge, Propagation Techniques

\section{Introduction}

Indigenous fruit trees (IFTs) have since time immemorial played a significant role towards rural livelihood enhancement [1], [2]. Some IFTs are deliberately managed on-farm for their vital contribution to food security as they provide essential nutrients such as carbohydrates, lipids/fats, proteins, vitamins and minerals [3], [4]. IFTs have also been widely reported to be sources of income as they have great market potential that is comparable to exotic fruits like mangoes and citrus [5], [6].

Garcinia buchananii commonly known as Granite mangosteen is one of such classic IFTs belonging to Clusiaceae family. The species is found in tropical climate including Eastern Africa [7]. In Uganda, the species is not common but widely distributed, ranging from very moist sites on the shores of Lake Victoria, particularly on the western shore, to very dry sites in North Eastern region.

Botanically, G. buchananii has been described to be a small evergreen tree with oblong and leathery leaves and fleshy, round and sour tasty fruit with a taste similar to that of Psidium guajava (guava) or Carica papaya (pawpaw), but with a sharp pungent smell [8]. It is often densely branched to a thick dark shady crown. All parts of the species contain a rather yellow sap. The bark is smooth, dark grey-brown, later rough and flaking. Flowers are white, yellow or orange, about $1 \mathrm{~cm}$ across, female solitary, male in clusters of 2-3, 4 petals and sepals around a sticky orange centre [9].

In areas where it grows, G. buchananii is not only considered as food with its edible fruits [10], but also as medicine. In African ethnomedicine, a concoction from the bark and roots of G. buchananii is reported to treat 
cryptococcal meningitis, skin rashes, tuberculosis and chronic diarrhea [11].Chemical evaluation of the fruits extract of G. buchananii also indicates that it contains bioactive compounds that are widely believed to reverse weight loss in humans [12].

Although G. buchananii has enormous food and medicinal uses, it is either semi managed on farm or it is found in the wild. Of recent, farmers have discovered that G. buchananii on farm can help in maintaining soil fertility and also moderate agro-climate [13]. While G. buchananii is beginning to become domesticated on farm, information on the management and occurrence within the LVB is still scarce. This paper therefore explores the prevalence and availability of $G$. buchananii and management practices within the Lake Victoria Basin (LVB) districts of Rwanda and Uganda.

\section{Materials and Methods}

\subsection{Study Area, Sampling Strategy and Data Collection Process}

The study was conducted within the LVB, covering the districts of Bugesera and Kirehe in Rwanda; and Buikwe and Masaka in Uganda. These districts were purposively selected following prior studies [14], [15], [16] that indicated a more conducive climate and relative abundance of G. buchananii. Household interviews were conducted in each of these districts using questionnaires, key informant interviews, focus group discussions (FGDs) and case studies with interest largely focused on developing insights about availability of $G$. buchananii, their ecological niche(s), propagation and management practices. In total, 360 household heads were interviewed with 100 questionnaires administered in each districts in Rwanda and 80 in each district in Uganda. In each district, two sectors and two sub counties were purposively selected for the survey in Rwanda and Uganda, respectively. In each sector/sub-county, two cells in Rwanda and two parishes in Uganda were randomly selected. In each sector and sub county, two cells and two parishes were randomly selected. Similarly, two villages were randomly selected in each cell and parish in Rwanda and Uganda, respectively. In total, eight villages were thus selected from each district for the household surveys.

Face-to-face interviews using semi-structured questionnaires were then conducted with heads of sampled households. Household surveys were followed by FGDs that were held in two cells (in the case of Rwanda) and parishes (in the case of Uganda) with the aim of validating the household survey data and collating data on the availability status and ecological niches of G. buchananii. A total of 8-15 members (those who participated in the household survey) of the same sex were mobilized for the two FGDs session in each cell/parish. Separation by gender was done to capture the variability in the perceptions about the species. The FGDs were later followed by more in-depth case studies especially on the on-farm management practices of $G$. buchananii. Case studies were limited to two selected communities in each district. A community accessing $G$. buchananii was taken as a case because the species existed in few homes. These communities were people who had $G$. buchananii species on their land and were considered to be more knowledgeable about the species.

\subsection{Data Analysis}

Quantitative data from household interviews were coded and entered in Statistical Package for the Social Sciences (SPSS) software (version 20). Descriptive statistics were computed to show the availability, ecological niche(s) and propagation techniques of $G$. buchananii. Logistic regression analysis was run to assess the influence of social and demographic characteristics (such as age, sex, education level, period of stay on the land and income) on growing niches and propagation techniques of G. buchananii. Factor analysis was used to see the association among factors on availability, location and propagation techniques of $G$. buchananii. For this to successful, dummy variables were created for all the variables to be included in the factor analysis. Data from case studies, informal interviews and FGDs were subjected to content analysis based on emerging themes and patterns [17], [18]. In this study, a summative content analysis using latent content analysis [19] has been opted for in order to bring out difference and similarities in the ways IFTs are managed in both countries.

\section{Results}

\subsection{Demographic Characteristics of Respondents}

The demographic characteristics indicated that the mean age of respondents was $39 \pm 12$ in Rwanda and $52 \pm 16$ in Uganda. In terms of sex, male respondents were majority in Uganda (46.5\%) and Rwanda (58\%). Regarding marital status, most of the participants are married in Rwanda $(86.7 \%$ and in Uganda (70.6\%) while majority of respondents had attended primary education in both Rwanda (65.8\%) and Uganda (53.1\%). The main occupation of most respondents was farming in both countries. In terms of land possession, majority indicated to have their own land in both countries and the mean period spent in in Rwanda and in Uganda were $15 \pm 13$ and $33 \pm 18$, respectively. The monthly income of respondents in Rwanda was $26 \pm 44$ USD while that of Uganda was $63 \pm 171$ USD (Table 1). 
Table 1. Demographic data of respondents in Rwanda and Uganda

\begin{tabular}{|c|c|c|c|c|c|c|}
\hline & $\begin{array}{c}\text { Bugesera } \\
(\mathrm{N}=100)\end{array}$ & $\begin{array}{c}\text { Kirehe } \\
(\mathrm{N}=100)\end{array}$ & $\begin{array}{c}\text { Total Rwanda } \\
\text { (200) }\end{array}$ & Buikwe (N=80) & $\begin{array}{c}\text { Masaka } \\
(\mathrm{N}=\mathbf{8 0})\end{array}$ & $\begin{array}{c}\text { Total Uganda } \\
\text { (160) }\end{array}$ \\
\hline \multicolumn{7}{|l|}{ Age (Years) } \\
\hline Mean \pm SD & $38 \pm 12$ & $39 \pm 12$ & $39 \pm 12$ & $54 \pm 16$ & $50 \pm 15$ & $52 \pm 16$ \\
\hline Min & 18 & 21 & 18 & 20 & 23 & 20 \\
\hline Max & 70 & 73 & 73 & 102 & 92 & 102 \\
\hline Median & 35 & 38 & 37 & 52 & 50 & 51 \\
\hline \multicolumn{7}{|l|}{$\operatorname{Sex}(\%)$} \\
\hline Male & 48.0 & 67.4 & 58 & 41.3 & 41.7 & 46.5 \\
\hline Female & 51.0 & 32.6 & 42 & 58.7 & 58.3 & 53.5 \\
\hline \multicolumn{7}{|c|}{ Marital status } \\
\hline Single & 8.2 & 6.1 & 7.1 & 6.3 & 8.5 & 7.5 \\
\hline Married & 83.5 & 89.9 & 86.7 & 67.5 & 74.4 & 70.6 \\
\hline Divorced & 1.0 & 1.0 & 1.0 & 3.8 & 7.3 & 5.6 \\
\hline Widowed & 7.2 & 3.0 & 5.1 & 22.5 & 9.8 & 16.3 \\
\hline \multicolumn{7}{|c|}{ Level of Education (\%) } \\
\hline None & 26.3 & 20.2 & 24.0 & 27.4 & 15.0 & 21.3 \\
\hline Primary & 65.7 & 66.7 & 65.8 & 51.3 & 56.2 & 53.1 \\
\hline Secondary & 7.1 & 13.1 & 10.2 & 20.0 & 17.5 & 25.6 \\
\hline College & 1.0 & - & - & 1.3 & 11.3 & - \\
\hline \multicolumn{7}{|c|}{ Main occupation (\%) } \\
\hline Farming & 100 & 98.9 & 99.4 & 92.6 & 95 & 93.1 \\
\hline Civil service & - & - & - & 2.5 & 3.8 & 3.1 \\
\hline Business & - & 1.1 & 0.5 & 1.3 & 1.3 & 1.3 \\
\hline Others & - & - & - & 2.5 & - & 2.5 \\
\hline \multicolumn{7}{|l|}{ Have land } \\
\hline Yes & 82.7 & 95.9 & 90.9 & 96.3 & 100 & 98.1 \\
\hline No & 16.3 & 2.0 & 9.1 & 3.7 & - & 1.9 \\
\hline \multicolumn{7}{|l|}{ Period stayed } \\
\hline Mean \pm SD & $18 \pm 16$ & $11 \pm 6$ & $15 \pm 13$ & $32 \pm 19$ & $31 \pm 17$ & $33 \pm 18$ \\
\hline Min & 0 & 1 & 0 & 02 & 02 & 2 \\
\hline Max & 65 & 33 & 65 & 70 & 90 & 90 \\
\hline Median & 15 & 11 & 12 & 30 & 30 & 32 \\
\hline \multicolumn{7}{|c|}{ Monthly income } \\
\hline Mean \pm SD & $16 \pm 19$ & $39 \pm 56$ & $26 \pm 44$ & $46 \pm 217$ & $78 \pm 103$ & $63 \pm 171$ \\
\hline Min & 0 & 0 & 0 & 0 & 0 & 0 \\
\hline Max & 114 & 286 & 286 & 1923 & 769 & 1923 \\
\hline Median & 7 & 14 & 10 & 2 & 38 & 23 \\
\hline
\end{tabular}

\subsection{Community Knowledge on Availability Status of Garcinia Buchananii}

Descriptive statistics (Table 2) indicated that $G$. buchananii was perceived to be abundant, occasionally present, scarce and rare. Results on mean availability of $G$. buchananii indicated that the species was perceived to be mostly abundant in both countries $(0.329 \pm 0.471)$. The species was also reported to be occasionally present $(0.221 \pm 0.417)$ and scarce $(0.307 \pm 0.463)$. The lowest number of respondents confirmed that $G$. buchananii was rare $(0.143 \pm 0.351)$ in both countries.

With factor analysis on availability status of $G$. buchananii, results on variation among factors (variables) (Table 3) indicated that factor 4 was excluded from the association. Only the first three factors were retained in the process. Factor 1 standing for variable 1 (abundance) in the association showed the strongest association to the underlying latent variable with factor loading or variance of $36.596 \%$. This was followed by factor 2 (occasionally present) (33.133\%) and 3 (scarce) with $30.271 \%$ of variance. The species is thus more abundant and this has a big implication in the management of the species.

Table 2. Descriptive statistics on the availability status of G. buchananii

\begin{tabular}{cccc}
\hline & Mean & Std. Deviation & Analysis N \\
\hline Abundant & .329 & .471 & 140 \\
$\begin{array}{c}\text { Occasionally } \\
\text { present }\end{array}$ & .221 & .417 & 140 \\
Scarce & .307 & .463 & 140 \\
Rare & .143 & .351 & 140 \\
\hline
\end{tabular}


Table 3. Variance among components

\begin{tabular}{|c|c|c|c|c|c|c|c|c|c|}
\hline \multirow{2}{*}{ Component } & \multicolumn{4}{|c|}{ Initial Eigenvalues } & \multicolumn{2}{c|}{ Extraction Sums of Squared Loadings } & \multicolumn{3}{|c|}{ Rotation Sums of Squared Loadings } \\
\cline { 2 - 10 } & Total & $\begin{array}{c}\% \\
\text { of Variance }\end{array}$ & $\begin{array}{c}\text { Cumulative } \\
\%\end{array}$ & Total & $\begin{array}{c}\% \\
\text { of Variance }\end{array}$ & $\begin{array}{c}\text { Cumulative } \\
\%\end{array}$ & Total & $\begin{array}{c}\% \\
\text { of variance }\end{array}$ & $\begin{array}{c}\text { Cumulative } \\
\%\end{array}$ \\
\hline 1 & 1.467 & 36.674 & 36.674 & 1.467 & 36.674 & 36.674 & 1.464 & 36.596 & 36.596 \\
\hline 2 & 1.337 & 33.426 & 70.100 & 1.337 & 33.426 & 70.100 & 1.325 & 33.133 & 69.729 \\
\hline 3 & 1.196 & 29.900 & 100.000 & 1.196 & 29.900 & 100.000 & 1.211 & 30.271 & 100.000 \\
\hline 4 & $9.936 \mathrm{E}-16$ & $2.484 \mathrm{E}-14$ & 100.000 & & & & & & \\
\hline
\end{tabular}

- Extraction Method: Principal Component Analysis

However, the scree plot (Fig. 1) revealed that the first three factors are highly associated since the slope of the curve levels down after just three factors rather than four factors. Availability of $G$. buchananii was then squeezed between abundant, occasionally present and scarce.

\section{Scree Plot}

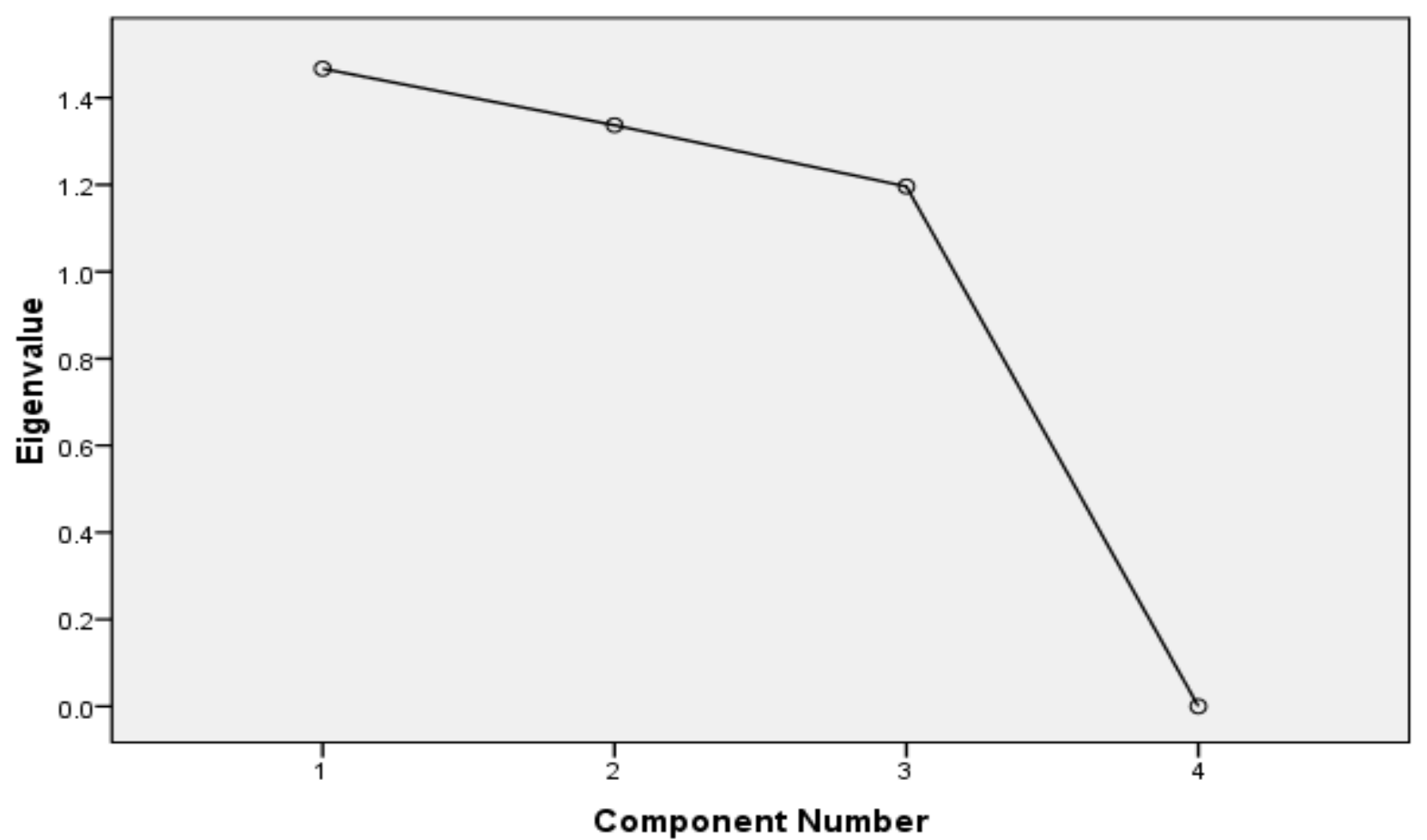

Figure 1. Scree plot graph showing curve slop level of factors

\subsection{Ecological Niche(s) of Garcinia buchananii}

Ecologically, G. buchananii was mostly reported to be present in the wild in Rwanda (52.9\%) while $37.3 \%$ reported the species to be found in the garden and $9.8 \%$ in the compound. In Uganda, G. buchananii was mostly reported to be located in the garden (53.2\%) followed by compound (31.2\%) and in the wild (15.6\%). (Figure 2)

\subsubsection{Factors Influencing Community Knowledge on the Location of Garcinia buchananii}

Results on logistic regression analysis on factors influencing knowledge on the location of G. buchananii indicated that education $\left(R^{2}=0.024 ; p=0.05\right)$ and occupation $\left(R^{2}=0.088 ; p=0.05\right)$ community knowledge on the location of the species in Rwanda while none of the socio-demographic characteristics of the respondent's influence community knowledge on the location of G. buchananii (Table 4). 


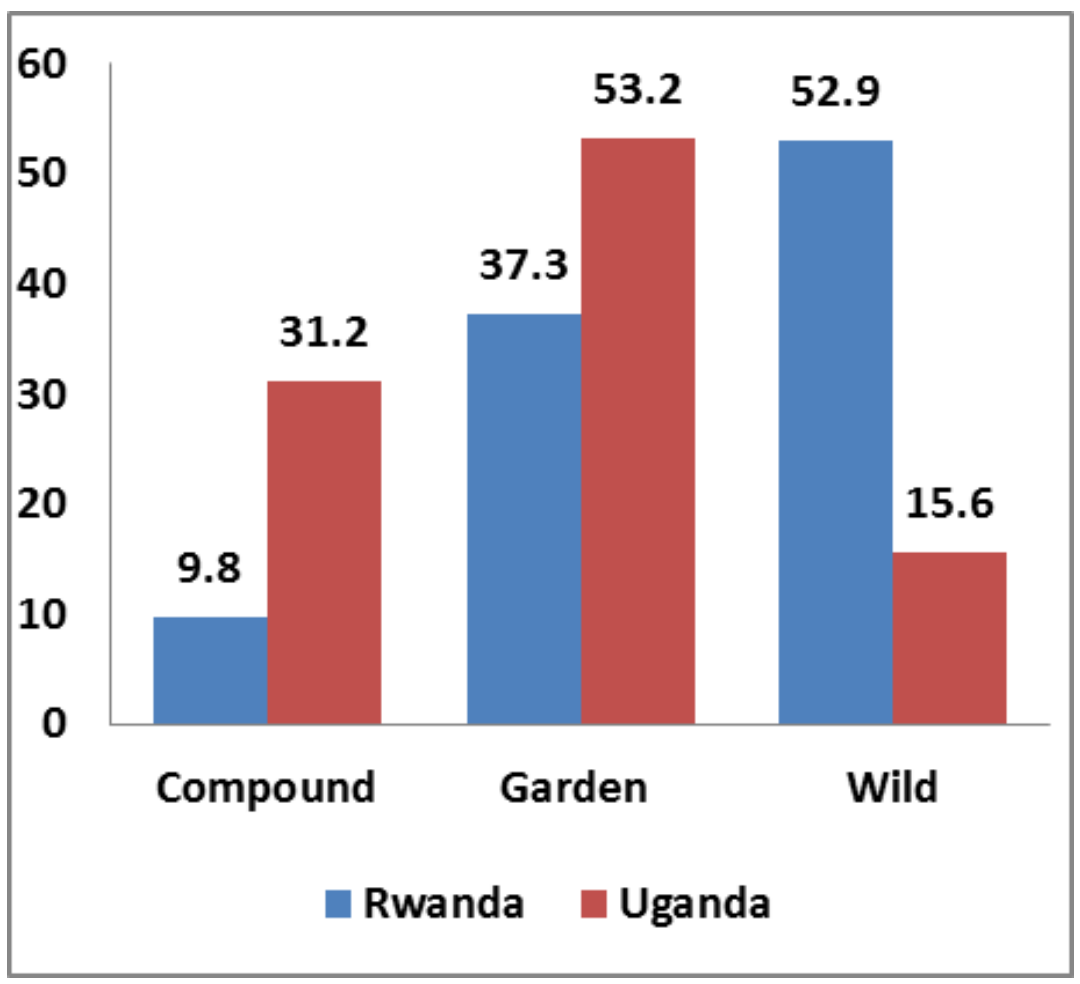

Figure 2. Ecological niches of Garcinia buchananii in Rwanda and Uganda

Table 4. Logistic regression of factors influencing community knowledge on location of G. buchananii

\begin{tabular}{|c|c|c|c|c|c|}
\hline \multirow[t]{2}{*}{ Factors } & \multicolumn{2}{|c|}{ Rwanda } & \multirow[b]{2}{*}{$\mathrm{R}^{2}$} & \multicolumn{2}{|c|}{ Uganda } \\
\hline & S.E & Sig. & & S.E & Sig. \\
\hline Age & 0.010 & 0.363 & & 0.007 & 0.568 \\
\hline Sex & 0.176 & 0.139 & & 0.189 & 0.904 \\
\hline Marital status & 0.160 & 0.276 & & 0.116 & 0.155 \\
\hline Education & 0.190 & $0.017 *$ & 0.024 & 0.138 & 0.228 \\
\hline Occupation & 0.183 & $0.001 *$ & 0.088 & 0.060 & 0.845 \\
\hline Period stayed in the village & 0.006 & 0.053 & & 0.006 & 0.732 \\
\hline Income & 0.005 & 0.832 & & 0.001 & 0.904 \\
\hline
\end{tabular}

$*=$ significant at $\mathrm{p} \leq 0.05$

In addition to logistic regression on factors influencing farming community knowledge on the location of G. buchananii, results on factor analysis of association of variables (Table 5) indicated that compound and garden were retained during the exclusion. Wild was excluded in the association during factor analysis. Factor 1 showed a strong association with variance of $53.074 \%$ followed by factor $2(46.926 \%)$.

Table 5. Total Variance Explained

\begin{tabular}{|c|c|c|c|c|c|c|}
\hline \multirow{2}{*}{ Component } & \multicolumn{3}{|l|}{} & \multicolumn{3}{c|}{ Rotation Sums of Square Loadings } \\
\cline { 2 - 7 } & Total & $\%$ of variance & Cumulative \% & Total & $\%$ of Variance & Cumulative \% \\
\hline 1 & 1.624 & 54.127 & 54.127 & 1.592 & 53.074 & 53.074 \\
\hline 2 & 1.376 & 45.873 & 100.000 & 1.408 & 46.926 & 100.000 \\
\hline
\end{tabular}




\subsection{Knowledge on Techniques for Propagating Garcinia buchananii}

\section{Extraction Method: Principal Component Analysis}

Majority of respondents reported that $G$. buchananii was propagated by use of seeds in both Rwanda (85.4\%) and Uganda (87.8\%).FGDs show that men were more knowledgeable about the propagation of the species using seeds compared to women in Rwanda. Use of roots $(2.0 \%$ of the respondents), stem $(2.0 \%)$ and wildlings $(8.2 \%)$ were also reported by the respondents for propagating $G$. buchananii in Uganda. (Table 6)

\subsubsection{Factors Influencing Community Knowledge on Propagation of Garcinia buchananii}

While there was no significant influence of the respondents' socio-demographic characteristics on knowledge of propagation techniques in Rwanda, in Uganda, (particularly in Buikwe district), only occupation significantly influenced knowledge on propagation of $G$. buchananii $\left(\mathrm{R}^{2}=0.084 ; \mathrm{p}=0.05\right)$ (Table 7$)$. There might be other factors that influence peoples' knowledge on propagation technique in Rwanda.

With factor analysis, results on curve slop level of factors (Fig. 3) revealed that there is a remarkable slop of the curve. From propagation of $G$. buchananii by use of roots to propagation of the species by use of seeds, the slope is high. But between propagation by use of seeds and propagation by use of stem cutting is a bit straight which means using seeds as a propagation technique was the most reported by the community and would be recommended to those willing to domesticate the species. A high slope is also between the third and the fourth factor.

Table 6. Reported techniques for propagation of Garcinia buchananii

\begin{tabular}{ccc}
\hline Propagation technique & Rwanda (N=200) & Uganda (N=160) \\
\hline By use of roots & - & $2.0(1)$ \\
By use of seeds & $85.4(35)$ & $87.8(43)$ \\
By use of stem cutting & - & $2.0(1)$ \\
By use of wildlings/seedlings & $14.6(6)$ & $8.2(4)$ \\
\hline
\end{tabular}

Table 7. Logistic regression of factors influencing farmers' knowledge on propagation techniques of G. buchananii in Rwanda and Uganda

\begin{tabular}{ccccc}
\hline & \multicolumn{2}{c}{ Rwanda } & \multicolumn{2}{c}{ Uganda } \\
\hline Factors & S.E & Sig. & S.E & Sig. \\
\hline Age & 0.012 & 0.354 & 0.005 & 0.781 \\
Sex & 0.263 & 0.967 & 0.144 & 0.182 \\
Education & 0.227 & 0.880 & 0.115 & 0.366 \\
Occupation & 0.281 & 0.247 & 0.067 & $0.020^{*}$ \\
Period of stay on the land & 0.009 & 0.714 & 0.006 & 0.469 \\
Income & 0.003 & 0.831 & 0.001 & 0.289 \\
\hline
\end{tabular}

*=significant at $\mathrm{p} \leq 0.05, \mathrm{R}^{2}=0.084$

\section{Scree Plot}

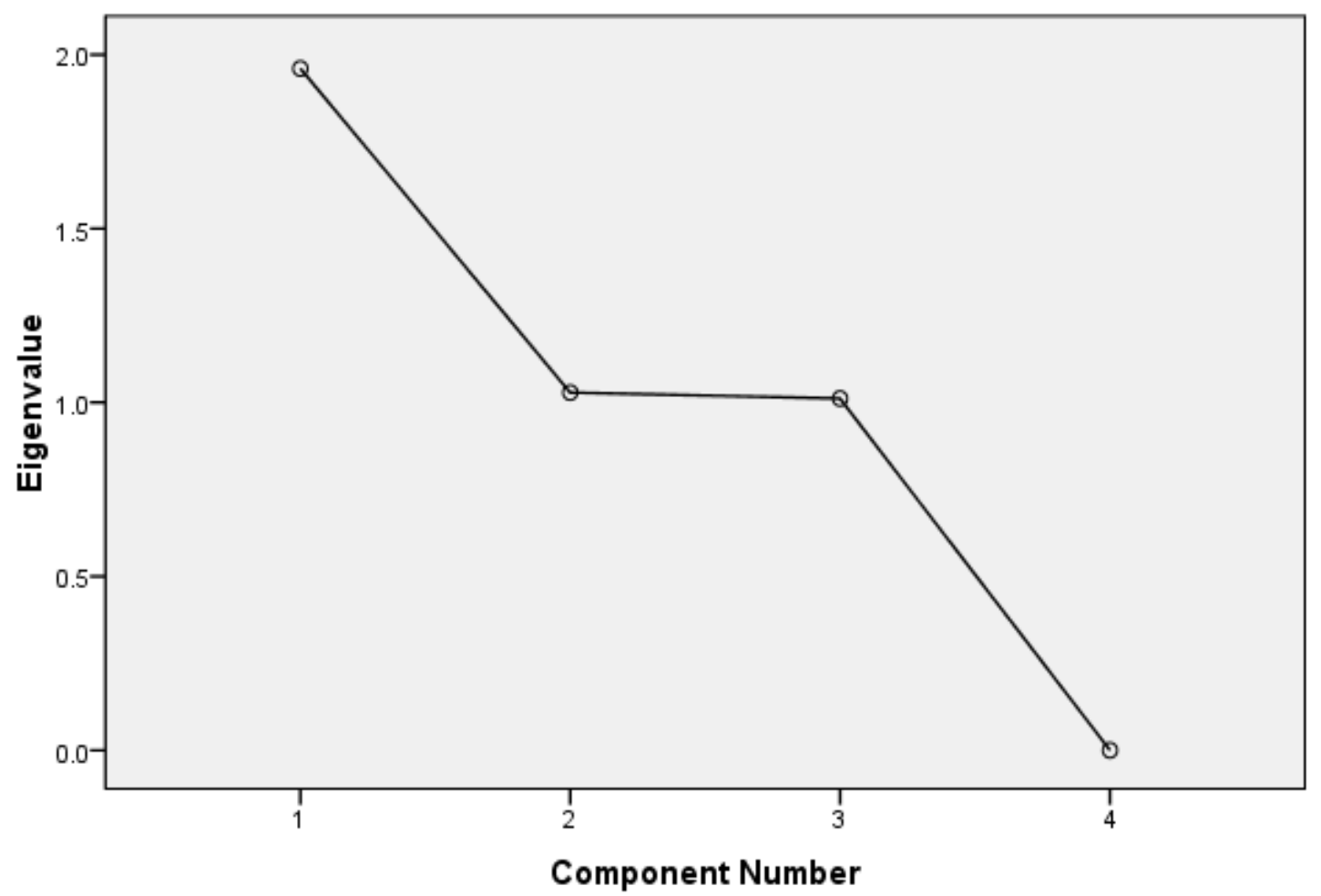

Figure 3. Scree plot graph showing curve slop level of factors 


\subsection{Reported on-farm Management Practices of Garcinia buchananii}

Findings from interviews, FGD and case study indicated array of issues surrounding the management of $G$. buchananii in the study areas. Most of the management issues are clustered around phenological and resource use stages such as sapling, leafing, branching, flowering, fruiting and harvesting. At sapling phase of growth for example, most management activity was related to protecting the young and to increase its survivability. Such activities included watering and weeding the saplings and fencing the saplings to prevent them from being trampled upon by humans and domestic animals. Weeding, pruning and protecting the species from being animals and humans were reported as common management practices in both countries (Table 8).

\section{Discussion}

\subsection{Perceived Availability Status of Garcinia buchananii}

G. buchananii was reported to be more abundant in the areas where the study was conducted. In fact, the two districts in Rwanda where the study was conducted are semi-arid and have savanna vegetation type. Bugesera district particularly is predominantly vegetated by dry savannas which are characterized by short grasses, shrubs and short trees characteristic of arid and semi-arid area [20]. Our observations also indicated that considerable parts of the districts were covered with shrubby vegetation which may favor abundance of the species. In Uganda, in addition to the presence of tree species favoring abundance of $G$. buchananii, the two districts have also more arable land compared to the study districts in Rwanda where the species has been retained on farm with other plants. Information on availability of $G$. buchananii provides a sound basis for its domestication and sustainable management. This can be a strategy to raise farmers' willingness to invest in on-farm management of the species.

\subsection{Reported Ecological Niches of Garcinia buchananii}

The fact that G. buchananii is given little value in Rwanda, it makes it not domesticated and hence present in the wild. Farmers do not transplant G. buchananii; which makes the species absent in the arable land but rather grow wildly. It is therefore difficult for small-scale farmers to access the species. In Uganda, however, the species is mostly found in the garden because people have tried to transplant the species. You find the species in the field and in some people's compound. This implies that farmers know much about the species.

The presence of G. buchananii in the wild (Rwanda) and garden (Uganda) may be due to type of land management. It is clear that the species is riskier in Rwanda because it is mostly found in the wild land. Therefore, it may not be easy to sensitise and convince farmers on the domestication of the species. However, the more people are educated, the more knowledgeable about the ecological location are. Thus, educated people who also practice farming would be the best pathways in promoting sustainable management of $G$. buchananii. In Uganda, on the contrary, the domestication of the species would be better understandable because the species is getting close to homes. Being present in the garden is an occasion for the farmers to be more knowledgeable about the species.

Table 8. Management practices towards G. buchananii

\begin{tabular}{|c|c|c|}
\hline \multirow{2}{*}{ Stage } & \multicolumn{2}{|c|}{ Activity } \\
\hline & Rwanda & Uganda \\
\hline Sapling & $\begin{array}{c}\text { Weeding when it is about } 30 \mathrm{~cm} \text { diameter. } \\
\text { Fencing to protect from being trampled and browsed by animals. } \\
\text { Digging around to make the soil more fertile and loose. } \\
\text { Watering the plant. }\end{array}$ & $\begin{array}{l}\text { When transplanted, root pruning is avoided to prevent } \\
\text { drying of the plant. } \\
\text { Fencing of the transplant to safeguard it against livestock. } \\
\text { Weeding when planted with other crops. }\end{array}$ \\
\hline Leafing & No specific activity & $\begin{array}{c}\text { Weeding and safeguarding to protect from livestock } \\
\text { especially browsers. }\end{array}$ \\
\hline Branching & $\begin{array}{l}\text { Pruning to make the tree grow well and straight (when it is } 1 \mathrm{~m} \\
\text { high) } \\
\text { Pruning (when old) so that it can put on new branches that can } \\
\text { produce more fruits. } \\
\text { Protecting against children } \\
\text { Protecting the tree from livestock }\end{array}$ & $\begin{array}{l}\text { Pruning to protect the plant against children who would } \\
\text { climb and break the branches } \\
\text { Weeding to protect against fire }\end{array}$ \\
\hline Flowering & $\begin{array}{c}\text { Safeguarding to prevent children from removing the flowers } \\
\text { Weeding around the tree }\end{array}$ & Weeding to protect it against fire. \\
\hline Fruiting & $\begin{array}{l}\text { Discouraging picking/harvesting of the fruits when they are not yet } \\
\text { mature and ripe. }\end{array}$ & Fencing to protect fruits from being harvested by children \\
\hline Harvesting & $\begin{array}{l}\text { Climbing and picking ripe fruits from all branches of the tree } \\
\text { mainly children. }\end{array}$ & $\begin{array}{l}\text { Harvesting of ripe fruits especially by hooking the fruits } \\
\text { down using long sticks; climbing and selectively hand } \\
\text { picking the ripe fruits; shooting down the ripe fruits using } \\
\text { throwable objects like stones and short sticks. }\end{array}$ \\
\hline
\end{tabular}


In addition, compound and garden showed a strong association during factor analysis which means they are regarded as the most locations where the species is found. Having wild excluded in the association shows that it can't go with the two factors in the combination as it is the most reported location especially in Rwanda. It has a high influence on other locations of the species. Location of the species influences much its management. There will therefore be more willingness and encouragement to carry out management practices in Uganda than in Rwanda.

\subsection{Reported Propagation Techniques of Garcinia buchananii}

Seeds remained the most reported propagation technique of G. buchananii. As has been highlighted in other studies, use of seeds remains the most popular propagation technique that allows genetic diversity [21]. It would be therefore important if seeds of $G$. buchananii are made available and distributed to farmers. One of the advantages of using seeds to stems in propagation is that each plant is able to produce a huge number of seedlings [22].This can be one of the strategies to raise and increase awareness about benefits the species provides; hence increasing willingness of on-farm domestication of the species. Men, being more knowledgeable about propagation are one opportunity to spread knowledge on the sustainable use and management of G. buchananii. In promoting on-farm domestication of the species in Uganda, particularly in Buikwe, targeting people who have occupation especially those who practice farming would also be an advantage because of knowledge and value they might know about the species.

\subsection{Management Practices for Garcinia buchananii}

Smallholder farmers in both countries have attachment to G. buchananii. This is shown by different activities (weeding, mulching, fencing, pruning and harvesting) done towards the species. The reason of this interest could be the benefits such as fruits and medicine people attach to the species. That is why you find the species on some people's farms where it is protected like other crops. In Rwanda, many people still regard it as a wild species. It seems that these people do have not much information about the species. This would make the species destructed or overexploited by people, hence limiting the promotion of exploitation of benefits of the species.

Management plays a vital role to protect, rescue and safeguard species from being wiped out [23]. In the case of $G$. buchananii, management practices take place only when it is found in people's gardens and/or when it is with other crops in the garden. There is no management practice when the species is in the wild since it grows by itself. In the wild, the species lacks protection; hence gets destructed by people or animals. Besides, people do not have access to the fruits easily since they may not be aware of the presence of the species. It is therefore left there until it produces fruits. The only activity done is collecting the fruits when they are ready. The fruit tree species is considered as a wild tree. Some people in Bugesera even affirmed that the species grows wild and there is no need to take care of it. Despite this, there are various management practices done to the species by the farmers especially when it is in arable land with other crops.

Activities such as pruning help the species remain with branches that can yield much. Studies state that pruning helps good air circulation and light penetration to reduce mildew and other diseases [24]. Harvesting is the main activity but some harvesting strategies seem to be inappropriate and may cause injuries on fruits which can lead to post-harvest losses [25]. There is lack of norms on harvesting fruits that can also lead to over-exploitation which is a threat to the extinction of the species [26]. Proper management of $G$. buchananii would lead to high production; hence need to domesticate the species. There is therefore a need by policy makers and extension agents to formulate clear strategies on conservation of IFTs in general and $G$. buchananii in particular and encourage farmers to domesticate them on-farm.

\section{Conclusions}

Rural farmers in the LVB are knowledgeable about management of $G$. buchananii. Generally, the species is abundant and present in the gardens and wild. The species is mostly propagated by seeds but knowledge on propagation is mostly influenced by education, occupation, qualification and period stayed in the village. There are also different activities done towards the species from early stage up to the stage of harvesting the fruits. Management practices are related to protection of the species. This shows that local communities attach much interest on the species. Though communities in Uganda seem to be more knowledgeable about the species than communities in Rwanda, there is a need to increase people's awareness of the importance of the species through extension service. This would help in sustainable management of the species as a way of increasing yield and hence improve livelihood of the community.

\section{Acknowledgements}

We are grateful to the Inter-University Council for East Africa through VicRes Project for providing funds for this project. We also thank the communities in the districts in Uganda and Rwanda where the study was undertaken for their help, enthusiasm and hospitality during data collection. Special thanks go to Makerere University for granting time to conduct this study. 


\section{REFERENCES}

[1] K. Makdoh, M. B. Lynser, and K. H. M. Pala. Marketing of Indigenous Fruits: A Source of Income among Khasi Women of Meghalaya, North East India. J. Agric. Sc., vol. 5, no. 1-2, pp. 1-9, 2014.

[2] C. M. Mwema, J. K. Lagat and B. K. Mutai. Economics of harvesting and marketing selected indigenous fruits in Mwingi district, Kenya. 4th International Conference of the African Association of Agricultural Economists, September 22-25, 2013, Hammamet, Tunisia, 2013.

[3] B.A. Jama, A. M. Mohamed, J. Mulatya and A. N. Njui. Comparing the "Big Five": A framework for the sustainable management of indigenous fruit trees in the drylands of East and Central Africa. Ecol. Indicators, 8, pp. 170-179, 2007.

[4] P. O. Anegbeh, Z. Tchoundjeu, B. C. Anuforom, V. Ukafor, and C. Usoro. Farmers' participation in ex-situ conservation of indigenous fruit trees in Southern Nigeria. Nigeria. J. Agric. Soc. Res., vol.4, no. 2, 2004.

[5] G. J. Agea. Potential of domesticating indigenous fruit trees for food security and household incomes in Lira district. Research Report. Kampala-Uganda, 2004.

[6] T. Fukushima, Y. Morimoto, P. Maundu, B. Kahindi and J. Fondo. Local preference of indigenous fruit trees in Coast Province, Kenya. Nairobi, Kenya. Afr. J. Environ. Sci. Technol vol. 4, no. 12, pp. 872-885, 2010.

[7] J. J. Magadula and Z. H. Mbwambo. Garcinia Plant Species of African Origin: Ethnobotanical.

[8] Pharmacological and Phytochemical Studies. Open Science Publisher, ISBN: 978-1-941926-10-9, 2014

[9] P. Smith and Q. Allen. Field Guide to the Trees and Shrubs of the Miombo Woodlands Royal Botanic Gardens, Kew ISBN 184246073 0, 28 - 29, 2004.

[10] A. Maroyi. Traditional use of medicinal plants in south-central Zimbabwe: review and perspectives. J Ethnobiol Ethnomed, 9:31, 2013.

[11] O. B. Balemba, Y. Bhattarai, C. Stenkamp - Strahm, M. S. B. Lesakit and G. M. Mawe.The traditional antidiarrheal remedy, Garcinia buchananii stem bark extract, inhibits propulsive motility and fast synaptic potentials in the guinea pig distal colon. Neurogastroenterol Motil, vol. 22, pp.1332-1339, 2010.

[12] K. C. Chinsembu and M. Hedimbi. An ethnobotanical survey of plants used to manage HIV/AIDS opportunistic infections in Katima Mulilo, Caprivi region, Namibia. J Ethnobiol Ethnomed, pp. 6-25, 2010.

[13] P. A. Boakye, S. M. Brierley, S. P. Pasilis and O. B. Balemba. Garcinia buchananii bark extract is an effective anti-diarrheal remedy for lactose-induced diarrhea. J Ethnopharmacol, vol. 142, no. 2 pp. 539-547, 2012.

[14] C. Sebukeera, E. Muramira, C. Momokama, A. Elkholei, I.
Elbagouri, B. Masumbuko and V. Rabesahala. Forests and Woodlands in Africa. Environment Outlook 2: Our Environment, Our Wealth. UNEP, 196-209, 2006.

[15] J. Mwine, P. Van Damme., G. Kamoga, Kudamba, M. Nasuuna and F. Jumba Ethnobotanical survey of pesticidal plants used in South Uganda: Case study of Masaka district. J. Med. Plants Res. Vol. 5(7), pp. 1155-1163, 2011.

[16] REMA. Rwanda State of Environment and Outlook Report" Rwanda Environment Management Authority. Kigali, Rwanda, 2009.

[17] N. Biedinger and E. Fischer. Epiphytic vegetation and ecology in central African forests (Rwanda, Zaïre). Bonn, Germany. ECOTROPICA 2, pp. 121-142, 1996.

[18] M. B. Miles and A. M. Huberman. Qualitative Data Analysis, Second Edition. Sage Publications. New Delhi 110048 India, 1994.

[19] S. Elo and H. Kynga"s. The qualitative content analysis process. J Adv Nurs 62(1), 107-115doi: 10.1111/j, pp. 1365-2648, 2008.

[20] H-F. Hsieh and S. E. Shannon. Qualitative Health Research. Three Approaches to Qualitative Content Analysis. 2005. Qual Health Res 2005 15: 1277. DOI: 10.1177/1049732305276687, 2005.

[21] REMA. Pilot Integrated Ecosystem Assessment of Bugesera. UNEP/UNDP/GOR Poverty and Environment Initiative Project (PEI), Rwanda, 2007.

[22] S. A. Mng’omba, F. K. Akinnifesi, G. Sileshi, O. C. Ajayi, S. Chakeredza and W. F. Mwase. A decision support tool for propagating Miombo indigenous fruit trees of southern Africa. Lilongwe, Malawi. Afr J Biotechnol Vol. 7, no. 25, pp. 4677-4686, 2008.

[23] B. S. Somashekhar and M. Sharma. Propagation Techniques of Commercially Important Medicinal Plants. Andhra Pradesh State Forest Department, Bangalore, 2002.

[24] S. Padulosi, N. Bergamini and T. Lawrence, editors. On-farm conservation of neglected and underutilised species: status, trends and novel approaches to cope with climate change Proceedings of an International Conference, Frankfurt, 14-16 June, 2011. Biodiversity International, Rome, 2011.

[25] A. Nyambo, A. Nyomora, C. K. Ruffo and B. Tengnäs. Fruits and nuts: species with potential for Tanzania. Technical handbook, no. 34. Nairobi, Kenya, 2005.

[26] A. Iranbakhsh, M. Ebadi and Z. Zare. The contribution of indigenous fruit trees in sustaining rural livelihoods and conservation of natural resources. Iran. J. Hortic. For. Vol. 1(1): 001-006, 2009.

[27] E. Chifamba. Cultivation and commercialisation of indigenous fruit trees to improve household food security in dry regions of Buhera Zimbabwe. J. Sustainable Dev. Afr. (Volume 13, No.5, 2011). ISSN: 1520-5509. Clarion University of Pennsylvania, Clarion, Pennsylvania, 2011. 